\title{
BIOMASS ALLOCATION IN Ziziphus spina-christi AND THE INVASIVE SPECIES Prosopis juliflora
}

\author{
ALOCAÇÃO DE BIOMASSA EM Ziziphus spina-christi E ESPÉCIES INVASORAS \\ Prosopis juliflora
}

\author{
Thobayet S. ALSHAHRANI ${ }^{1}$ \\ 1. Associate Professor of Forest Ecology, Plant Production Dept., College of Food and Agricultural Sciences, King Saud University. \\ Riyadh, Saudi Arabia. thobayet@yahoo.com
}

\begin{abstract}
Invasion by the exotic species Prosopis juliflora has become a major threat to native plants in Saudi Arabia as the species continues its spread into different regions of the country. Ziziphus spina-christi is a native tree that is common in Saudi Arabia. The objective of this study was to determine how both species would benefit from the availability of sufficient resources without competition. To gain a better understanding of growth under such conditions, a greenhouse experiment was conducted in which seedlings of both species were grown under favorable conditions for 6 months. During this period, growth performance was evaluated three times at intervals of 30, 90, and 180 days. Growth performance varied between the two species during one or more of the studied periods. Significant differences between the species were observed for root mass fraction, number of root tips, root to shoot ratio, height, stem diameter, stem dry weight, stem mass fraction, leaf area, leaf mass fraction, and chlorophyll $a$ and $b$ contents. The relative growth rate (RGR) and relative height growth rate were higher in P. juliflora at 30-90 days, whereas leaf area ratio and net assimilation rate were higher for Z. spina-christi at 90-180 days. Remarkably, the RGR for diameter in P. juliflora was almost double that in Z. spina-christi at 30-90 days and 90-180 days. The results obtained reflect a strategic difference in the biomass allocation to different plant components by the two species, whereby P. juliflora allocates higher biomass to the stems and Z. spina-christi allocates higher biomass to the roots.
\end{abstract}

KEYWORDS: Saudi Arabia. Seedling. Resources. Root. Stem.

\section{INTRODUCTION}

In invaded regions, invasive alien species are released from the pressure of their native herbivores and parasites (KEANE; CRAWLEY, 2002), and the reduction in resources allocated to herbivore defense is invested in growth (BLOSSEY; NOTZOLD, 1995; TORCHIN et al., 2003). In an environment where resources are not limited, leaf traits are most important for successful invaders to take advantage with rapid growth, whereas integration with traits related to root tissue is an important factor for plant performance in different environments (DIAZ et al., 2004). Successful invasive species tend to allocate less biomass to roots than native species (WILLIAMS; BLACK, 1994; WILSEY; POLLEY, 2006), but tend to allocate high amounts of resources to stems and branches for canopy support (RADOSEVICH, et al., 2007). Under favorable conditions and without competition, invasive species generally have a higher relative growth rate (RGR), leaf area ratio (LAR), and/or specific leaf area (SLA) than related non-invasive species (FENG et al., 2008; GROTKOPP; REJMÁNEK, 2007; GROTKOPP et al., 2002). Disproportionate allocation to aboveground tissue is a pattern that enables invasive species to achieve high growth rates in undisturbed environments (BURNS et al., 2007).

Quantifying the growth rate of invasive species in contrast to natives is a starting point in understanding the dynamics of tree invasion. Many comparative studies have shown that native plant species have lower growth rates than invasive plants (AKASAKA; TSUYUZAKI, 2005; GLEASON; ARES, 2004). In most cases, higher growth rates are associated with the efficiency of using and allocating resources, which are traits that contribute to the higher performance of invasive species (PORTÉ et al., 2011). Consequently, higher resource allocation plasticity plays a key role in invasion (CALDWELL et al., 1981).

Most studies on plant growth have been designed to evaluate the response of plants to one or more stress conditions; however, only few studies have measured plant growth responses under favorable conditions. Variations in RGR among species are most apparent when plants are grown under favorable conditions (GROTKOPP; REJMÁNEK, 2007). The present study accordingly aimed to quantify RGR and biomass allocation and the patterns of resource allocation and utilization under favorable conditions in a native (Ziziphus spina-christi) and an invasive (Prosopis juliflora) 
woody plant species. The preliminary assumption made in this study was that both native and invasive species will exhibit the same patterns of resource allocation under the same growth conditions.

\section{MATERIAL AND METHODS}

Seeds of Z. spina-christi and P. juliflora were collected from 12 trees in central Saudi Arabia. Seeds of both species were separately sown in $10 \times 10 \times 32 \mathrm{~cm}$ plastic pots filled with sterilized sand. A total of 96 pots were established in monoculture, with 48 pots containing only $Z$. spinachristi and 48 pots containing only $P$. juliflora seedlings in a completely randomized design. A complete nutrient solution, Johnson's solution (JOHNSON et al., 1957), was used to fertilize the seedlings: $200 \mathrm{ml}$ per pot administered once a week throughout the experiment. The seedlings were grown in a greenhouse at $30^{\circ} \mathrm{C}(\mathrm{D} / \mathrm{N})$, and under a 13-hour photoperiod with illumination provided by HPS lights $(400 \mathrm{~W})$. Seedlings were watered with $120 \mathrm{ml}$ tap water once a week. On the basis of the complete unfolding of the first true leaf, plants were harvested at intervals of 30, 90, and 180 days thereafter.

For each interval and before harvesting plants, the following data were measured: number of leaves, plant height $(\mathrm{cm})$ from the cotyledon scars to the stem apex, and stem diameter $(\mathrm{mm})$ at the cotyledon scar using a digital caliper $( \pm 0.04 \mathrm{~mm})$. The number of leaves was counted for every seedling, and leaf area was measured for all leaves using a leaf area meter (L-COR 3100; LiCor Inc., Lincoln, NB, USA).

After removing soil from the roots with water, the roots of each species were spread over a computer scanner (UMAX $4000 \mathrm{U}$ with 1200 dpi by 2400 dpi resolution) and scanned at 600 dpi using Adobe Photoshop 5.5 (Adobe, 2001). The images were analyzed using WinRhizo software (Regent Instruments Inc., 2002) to measure total root length, volume, surface area, and number of tips. Roots, stems, and leaves were separately dried at $75^{\circ} \mathrm{C}$ for $48 \mathrm{~h}$ to obtain dry weights. RGR, net assimilation rate (NAR), and LAR were calculated according to Dash et al. (2013).

\section{Statistical analysis}

Data were statistically analyzed using the General Linear Model procedure in the Statistical Analysis System package (SAS 9.1 for Windows; SAS Institute Inc., Cary, NC, USA). Two-way ANOVA was used to examine the effect of species, days, and their interaction on dependent variables.
Multiple comparisons among pairs of means were performed using Bonferroni's multiple comparison test based on least square means, and all test results were evaluated at a significance level of $\alpha=0.05$.

\section{RESULTS}

The results presented below include only those showing a variation between the two species throughout the three harvest intervals. The variation in root traits was significant in one or more intervals, including root mass fraction, number of tips, and root to shoot ratio (Figure $1 \mathrm{~A}, \mathrm{~B}$, and $\mathrm{C}$ ). The root mass fraction and root to shoot ratio of the invasive species $P$. juliflora remained almost constant over time during the three harvest periods. In contrast, the root mass fraction and root to shoot ratio of $Z$. spinachristi increased over time. The total root length, root surface area, root volume, and root dry weight did not vary significantly between the two species during any harvest interval (Figure $1 \mathrm{D}, \mathrm{E}, \mathrm{F}$, and G, respectively).

Figure 2 shows the stem traits of height, diameter, dry weight, and mass fraction. The results indicated significant differences in stem traits between the two species in one or more interval. The height of $P$. juliflora seedlings increased rapidly and at the final harvest time, $P$. juliflora exceeded $Z$. spina-christi in height (Figure $2 \mathrm{~A}$ ). Stem diameter increased over time, and the diameter in the invasive species exceeded that in the native species at 90 and 180 days (Figure 2 B). Stem dry weight was significantly higher in $P$. juliflora than in $Z$. spinachristi at 90 and 180 days (Figure 2 C). Additionally, the stem mass fraction was higher for the invasive species compared to the native species. Stem mass fraction tended to be constant in the native species throughout the three harvest times (Figure 2 D). Total dry weight did not vary significantly between the two species during any harvest interval (Figure $2 \mathrm{E}$ ).

The results indicated that leaf area and leaf mass fraction were higher for $Z$. spina-christi compared to $P$. juliflora. Leaf area increased with time in both species (Fig. 3 A), but leaf mass fraction decreased with time in the two species (Figure $3 \mathrm{~B}$ ). SLA and leaf dry weight were not significantly different between the two species in any harvest interval (Figure $3 \mathrm{C}, \mathrm{D}$ ).

At 90 days, the leaf content of chl $a(\mu \mathrm{g} / \mathrm{ml})$ was significantly higher in $Z$. spina-christi compared with $P$. juliflora. In contrast, the chl $b$ content of $P$. juliflora was significantly higher at 30 days (Table 1). 




Figure 1. Changes over time in root traits for the native species Ziziphus spina-christi and the invasive species Prosopis juliflora. 


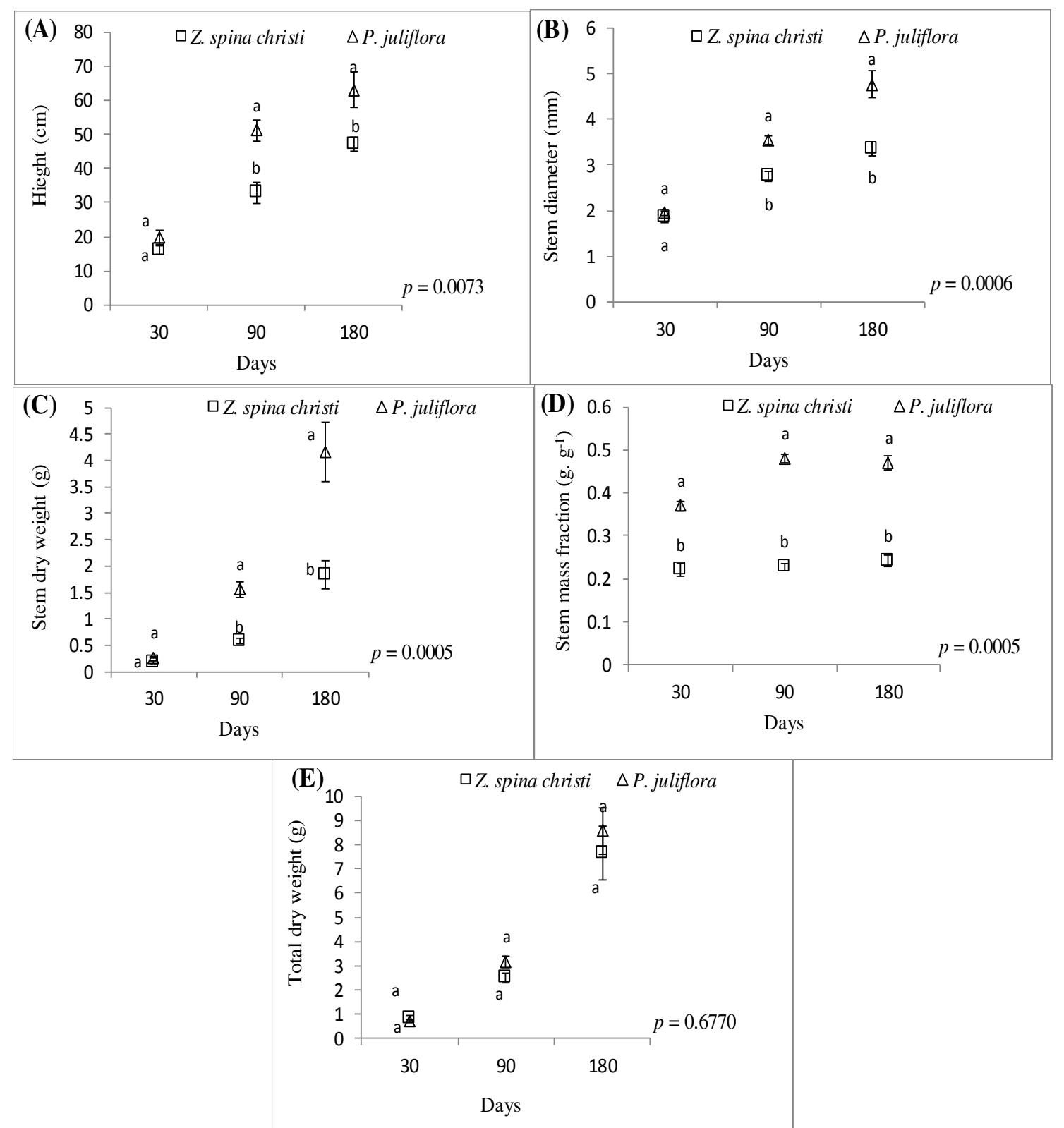

Figure 2. Changes over time in stem traits and total dry weight for the native species Ziziphus spina-christi and the invasive species Prosopis juliflora. 


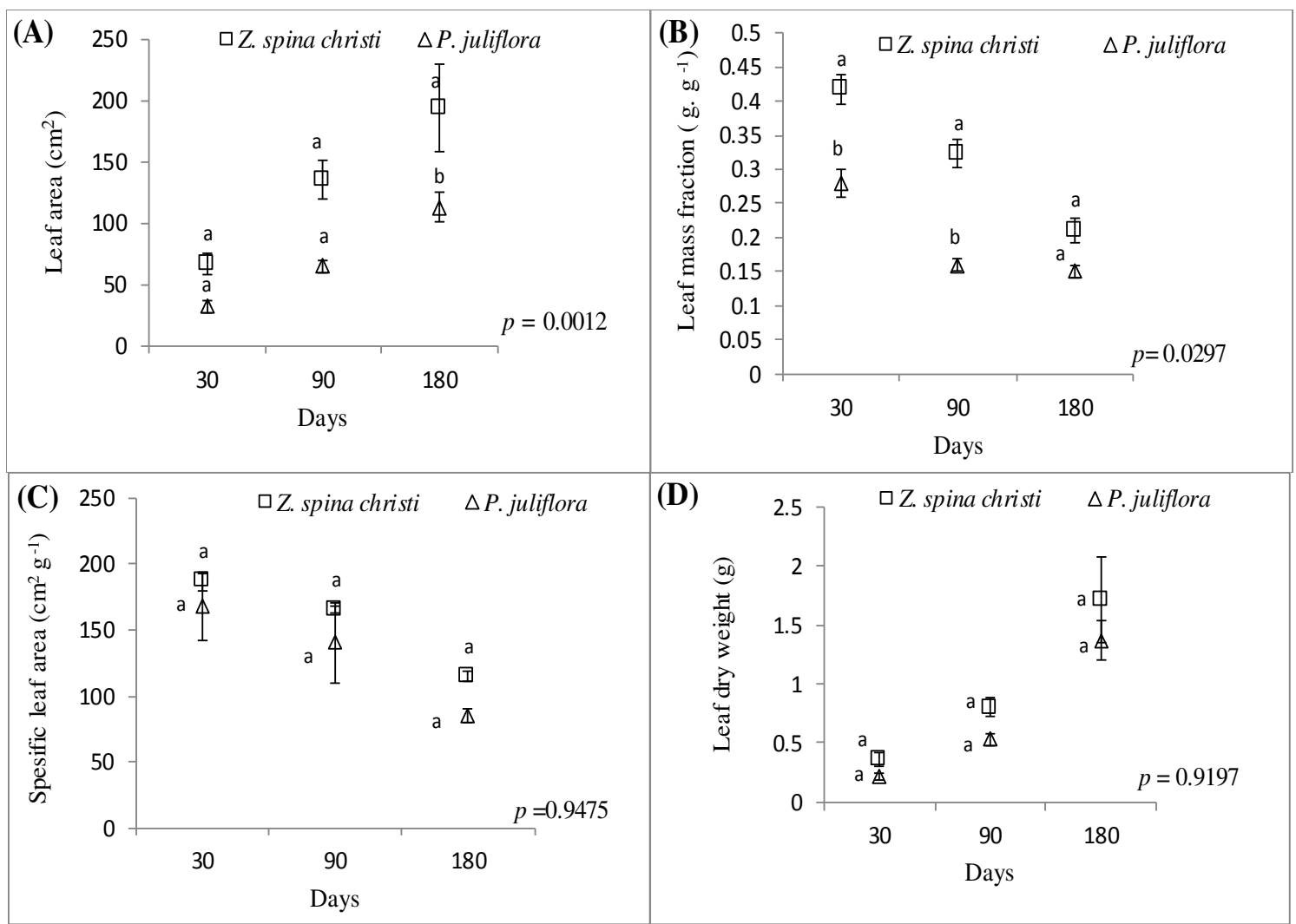

Figure 3. Changes over time in leaf traits for the native species Ziziphus spina-christi and the invasive species Prosopis juliflora.

Table 1. Chlorophyll $a$ and $b$ in Prosopis juliflora and Ziziphus spina-christi monitored for 30, 90, and 180 days.

\begin{tabular}{ccccccc}
\hline \multirow{3}{*}{ Species } & \multicolumn{3}{c}{ Chl $a \mu \mathrm{g} / \mathrm{mol}$} & \multicolumn{5}{c}{ Dhl $b \mu \mathrm{g} / \mathrm{mol}$} \\
\cline { 2 - 7 } & \multicolumn{3}{c}{ Days } & \multicolumn{5}{c}{30} & 90 & 180 \\
\cline { 2 - 7 } P. juliflora & 17.02 & 2.73 & 8.22 & 12.22 & 0.70 & 2.29 \\
& $(1.25)$ & $(0.1918)$ & $(0.5081)$ & $(1.2355)$ & $(0.1084)$ & $(0.0706)$ \\
Z. spina-christi & 18.34 & 12.22 & 10.27 & 5.58 & 3.31 & 3.07 \\
& $(0.3721)$ & $(0.4318)$ & $(0.7636)$ & $(0.1675)$ & $(0.1382)$ & $(0.0943)$ \\
Pr $>$ |t| & 0.5929 & 0.0004 & 0.4069 & 0.0025 & 0.2137 & 0.7054 \\
\hline *Data presented are ANOVA least square means (standard deviations in parentheses)
\end{tabular}

At 30-90 days, the relative height growth rate $\left(\mathrm{mm}^{-1}\right.$ day $\left.^{-1}\right)$ of $P$. juliflora $\left(0.52 \mathrm{~mm}^{-1}\right.$ day $\left.^{-1}\right)$ was significantly higher than that of $Z$. spina-christi $\left(0.28 \mathrm{~mm}^{-1}\right.$ day $\left.^{-1}\right)$; however, there was no significant difference in the relative height growth rate of the two species at 90-180 days (Table 2). There were no significant differences in root elongation rate $\left(\mathrm{mm}^{-1} \mathrm{day}^{-1}\right)$ of the two species at either 30-90 days or 90-180 days (Table 2). The relative diameter growth $\left(\mathrm{RGR}_{\mathrm{D}}: \mathrm{mm}^{-1} \mathrm{day}^{-1}\right)$ was significantly higher in $P$. juliflora during both growth periods, but showed a decrease in both species during the 90180-day period (Table 2).

At 30-90 days, the RGR ( $\left.\mathrm{mg} \mathrm{g}^{-1} \mathrm{~d}^{-1}\right)$ was higher in P. juliflora $\left(0.04 \mathrm{mg} \mathrm{g}^{-1} \mathrm{~d}^{-1}\right)$ (Table 3), whereas LAR $\left(\mathrm{cm}^{2} \mathrm{~g}^{-1}\right)$ and NAR $\left(\mathrm{mg} \mathrm{cm}^{-2} \mathrm{~d}^{-1}\right)$ were not significantly different between the two species (Table 3). In contrast, at 90-180 days, there was no significant difference in the RGR of the two species, but $Z$. spina-christi exhibited significantly higher LAR and NAR (Table 3). 
Table 2. Relative height growth rate, root elongation rate and diameter relative growth rate for Prosopis juliflora and Ziziphus spina-christi for two monitored periods.

\begin{tabular}{|c|c|c|c|c|c|c|}
\hline \multirow[t]{3}{*}{ Species } & \multirow{2}{*}{\multicolumn{2}{|c|}{$\begin{array}{l}\begin{array}{l}\text { Relative height growth } \\
\text { rate } \mathrm{mm}^{-1} \text { day }^{-1}\end{array} \\
\text { Days }\end{array}$}} & \multirow{2}{*}{\multicolumn{2}{|c|}{$\begin{array}{c}\begin{array}{c}\text { Root elongation rate } \\
\mathrm{mm}^{-1} \text { day }^{-1}\end{array} \\
\text { Days }\end{array}$}} & \multirow{2}{*}{\multicolumn{2}{|c|}{$\begin{array}{c}\begin{array}{c}\text { Diameter } \mathrm{RGR}_{\mathrm{D}} \\
\mathrm{mm}^{-1} \text { day }^{-1}\end{array} \\
\text { Days }\end{array}$}} \\
\hline & & & & & & \\
\hline & $30-90$ & $90-180$ & $30-90$ & $90-180$ & $30-90$ & $90-180$ \\
\hline P. juliflora & $\begin{array}{c}0.52 \\
(0.018)\end{array}$ & $\begin{array}{c}0.13 \\
(0.016)\end{array}$ & $\begin{array}{c}9.01 \\
(0.0103)\end{array}$ & $\begin{array}{c}5.47 \\
(0.3042)\end{array}$ & $\begin{array}{c}0.026 \\
(0.0016)\end{array}$ & $\begin{array}{c}0.013 \\
(0.0009)\end{array}$ \\
\hline Z. spina-christi & $\begin{array}{c}0.28 \\
(0.006)\end{array}$ & $\begin{array}{c}0.15 \\
(0.013)\end{array}$ & $\begin{array}{c}6.44 \\
(0.013)\end{array}$ & $\begin{array}{c}10.42 \\
(0.5096)\end{array}$ & $\begin{array}{c}0.014 \\
(0.0006)\end{array}$ & $\begin{array}{c}0.007 \\
(0.0003)\end{array}$ \\
\hline $\operatorname{Pr}>|t|$ & 0.0061 & 0.8341 & 0.4102 & 0.1545 & 0.0029 & 0.0014 \\
\hline
\end{tabular}

Table 3. Relative growth rate (RGR), Leaf Area Ratio (LAR) and Net Assimilation Rate (NAR) in Prosopis juliflora and Ziziphus spina-christi for two monitored periods.

\begin{tabular}{|c|c|c|c|c|c|c|}
\hline \multirow[t]{3}{*}{ Species } & \multirow{2}{*}{\multicolumn{2}{|c|}{$\frac{\begin{array}{c}\text { RGR } \\
\mathrm{mg} \mathrm{g}^{-1} \mathrm{~d}^{-1}\end{array}}{\text { Days }}$}} & \multirow{2}{*}{\multicolumn{2}{|c|}{$\begin{array}{l}\begin{array}{l}\text { LAR } \\
\mathrm{cm}^{2} \mathrm{~g}^{-1}\end{array} \\
\text { Days }\end{array}$}} & \multirow{2}{*}{\multicolumn{2}{|c|}{$\begin{array}{c}\begin{array}{c}\text { NAR } \\
\mathrm{mg} \mathrm{cm}^{-2} \mathrm{~d}^{-1}\end{array} \\
\text { Days }\end{array}$}} \\
\hline & & & & & & \\
\hline & $30-90$ & $90-180$ & $30-90$ & $90-180$ & $30-90$ & $90-180$ \\
\hline P. juliflora & $\begin{array}{c}0.040 \\
(0.001)\end{array}$ & $\begin{array}{c}0.059 \\
(0.0117)\end{array}$ & $\begin{array}{c}145.98 \\
(9.82)\end{array}$ & $\begin{array}{c}92.01 \\
(32.53)\end{array}$ & $\begin{array}{c}0.19 \\
(0.021)\end{array}$ & $\begin{array}{c}0.63 \\
(0.062)\end{array}$ \\
\hline Z. spina-christi & $\begin{array}{c}0.027 \\
(0.009)\end{array}$ & $\begin{array}{c}0.057 \\
(0.0116)\end{array}$ & $\begin{array}{l}162.12 \\
(8.03)\end{array}$ & $\begin{array}{l}134.03 \\
(47.38)\end{array}$ & $\begin{array}{c}0.44 \\
(0.050)\end{array}$ & $\begin{array}{c}1.83 \\
(0.34)\end{array}$ \\
\hline $\operatorname{Pr}>|t|$ & 0.0256 & 0.8719 & 0.5859 & $<.0001$ & 0.1625 & 0.0039 \\
\hline
\end{tabular}

\section{DISCUSSION}

Changes in biomass allocation toward plant organs are assumed to take place in order to maximize the capture of limited resources. However, the two species examined in the present study had different patterns of biomass allocation. There was a notable constancy in stem fraction throughout the experimental period in $Z$. spinachristi, whereas the root mass fraction was constant in P. juliflora. In dry tropical areas, the success of an invasive species depends mostly on the ability to allocate biomass to its different organs (GUPTA; NARAYAN, 2012). Invasive species, including shrubs, trees and grasses, tend to allocate most of their resources to the aboveground parts (stems, branches, and leaves) and less to roots (RADOSEVICH et al., 2007; WILLIAMS; BLACK, 1994; WILSEY; POLLEY, 2006; QIN et al., 2012).
Qin et al. (2012) showed that the invasive species Ambrosia artemisiifolia modified biomass allocation in response to different irradiance environments by increasing biomass allocation to stems and decreasing the allocation to roots at lower irradiance levels. This biomass allocation pattern indicates that successful invasion depends on environmental conditions. Alshahrani (2004) found that $P$. juliflora allocated above-ground biomass toward the stem instead of leaves, which contrasts to the allocation pattern in Z. spina-christi. However, the observed increase in shoot biomass concomitant with an increase in stem diameter in P. juliflora is consistent with the findings of Claridge and Franklin (2002). It is remarkable that the RGR for stem diameter in $P$. juliflora was approximately twice the value in Z. spina-christi for both 30-90day and 90-180-day intervals.

Successful invasion depends mainly on the efficiency with which invasive species use limited resources or on their ability to use them selectively 
at times when they are unavailable to the native species (VITOUSEK, 1996). Biomass allocation may also affect the success of invasive plants, whereby increasing biomass allocation to leaves may increase LAR. Indeed, some successful invasive species do allocate more biomass to leaves and less to roots than native species (KNAPP et al., 1998; WILLIAMS; BLACK, 1994; WILSEY; POLLEY, 2006). Although this pattern of biomass allocation may promote irradiance capture, it may also impair water and nutrient absorption, again indicating that invasion success may be environmentally dependent. The high root to shoot ratio in $Z$. spina-christi illustrated that species growing in nutritionally poor soils, e.g., desert, normally have higher biomass allocation to the roots (CHAPIN, 1980; LYNCH, 1995).

Although it is seldom found that an invasive species outperforms native species under all conditions (ZHENG et al., 2009), increasing resource availability often facilitates alien plant invasions (DAEHLER, 2003). Therefore, environmental conditions should be considered when identifying the traits contributing to invasiveness. However, these results of the present study were obtained under controlled conditions without nutrient or moisture shortage, and in the absence of other biotic interactions, e.g., speciesspecies interactions that could change the growth rate. Alshahrani (2004) found that under high levels of nitrogen, in mixed plantings, most measured parameters of $P$. juliflora exceeded the corresponding parameters of $Z$. spina-christi. Height, leaf area, total dry weight, and total chlorophyll $a b$ were reduced for $Z$. spina-christi seedlings grown with increasing proportions of $P$. juliflora. In addition, although $P$. juliflora tended to be more aggressive at high nitrogen levels, the aggressiveness and relative yield of $P$. juliflora decreased as its proportion increased in mixed culture. At low nitrogen levels, the growth of $Z$. spina-christi exceeded that of $P$. juliflora in most growth parameters, illustrating that $Z$. spina-christi had a competitive advantage over $P$. juliflora at low nitrogen levels.

The high RGR in $P$. juliflora may reflect the invasive plant's ability to achieve higher RGR by increasing the rate of photosynthesis or decreasing the rate of respiration (JAMES; DRENOVSKY, 2007). In the present study, there was a gradual decrease in LAR in both species during the experimental periods, and the differences in RGR may be due to a decrease in LAR, since LAR is the major component of RGR. Variations in LAR will thus have a significant effect on the values of RGR.
The reductions in SLA and LAR over time are consistent with the findings of Dias-Filho and De Carvalho (2000) and Crisóstomo et al. (2007). Prosopis juliflora tends to shed its leaves heavily under normal conditions (GOEL et al., 1989). This pattern indicates that invasive plants have less leaf area than natives (DURAND; GOLDSTEIN, 2001). Furthermore, the stability of the root mass fraction in P. juliflora may contribute to its higher RGR. Decreasing root systems in plants will decrease the root respiratory load, leading to increased carbon accumulation (D'ANTONIO et al., 2001).

Many studies have demonstrated that native species growing in arid and semiarid regions are adapted to soil nutrient deficiency and exhibit a lower RGR in comparison to their invasive counterparts (CRONK; FULLER, 1995; PATTISON et al., 1998; GARCIA-SERRANO et al., 2005). It is well known that invasive species have higher growth rates compared with natives (AKASAKA; TSUYUZAKI, 2005; GLEASON; ARES, 2004). The ecological advantage of a high RGR allows invasive plant to capture resources rapidly, occupy space, and reduce the time between vegetative growth and reproduction (POORTER, 1989). However, the low RGR of native species can be advantageous in that some researchers have suggested that natural selection in nutrient-poor environments has targeted one of the underlying components of RGR instead of RGR itself (LAMBERS; DIJKSTRA, 1987). For example, traits that contribute to the conservation and efficient use of resources in resource-poor systems are advantageous; however, these traits may simultaneously lower RGR. There is no strong agreement on whether introduced species differ from natives in their aboveground growth rates, and characteristics based on belowground growth are poorly understood. For instance, Vilà and Wiener (2004) found that native species exhibited greater aboveground growth rates in comparison with introduced species, whereas Ehrenfeld (2003) found that biomass and net primary productivity were higher in invaded sites in 14 out of 18 cases. Conversely, Daehler (2003) found no difference between native and introduced species.

In conclusion, the results of the present study reveal a strategic alteration in biomass allocation to different plant components under favorable conditions by an invasive ( $P$. juliflora) and a native ( $Z$. spina-christi) species over the course of the experiment. However, in contrast to $P$. juliflora, which allocated higher biomass to the stem, Z. spina-christi allocated higher biomass to the roots. It is important, nevertheless, to emphasize 
that these results were obtained under controlled conditions without nutrient or moisture deficiency and without biotic interactions.

RESUMO: Invasão pela espécie exótica Prosopis juliflora tornou-se uma grande ameaça para plantas nativas na Arábia Saudita à medida que a espécie continua a sua propagação em diferentes regiões do país. A Ziziphus spina-christi é uma árvore nativa que é comum na Arábia Saudita. O objetivo deste estudo foi determinar como ambas as espécies se beneficiariam com a disponibilidade de recursos suficientes sem competição. Para se obter uma melhor compreensão do crescimento nestas condições, foi conduzida uma experiência em estufa em que as plântulas de ambas as espécies foram cultivadas em condições favoráveis durante 6 meses. Durante este período, o desempenho de crescimento foi avaliado três vezes em intervalos de 30,90 e 180 dias. O desempenho do crescimento variou entre as duas espécies durante um ou mais dos períodos estudados. Diferenças significativas entre as espécies foram observadas para a fração de massa da raiz, número de pontas de raiz, razão entre a raiz e a parte aérea, altura, diâmetro do caule, peso seco do caule, fração de massa do caule, área foliar, fração de massa foliar e teor de clorofila a e b. A taxa de crescimento relativo (RGR, relative growth rate) e a taxa relativa de crescimento em altura foram maiores em P. juliflora no período 30-90 dias, enquanto que a razão foliar e a taxa de assimilação líquida foram maiores para Z. spina-christi no período 90-180 dias. Notavelmente, a RGR para o diâmetro em P. juliflora foi quase o dobro da de Z. spina-christi aos 30-90 dias e 90-180 dias. Os resultados obtidos refletem uma diferença estratégica na alocação de biomassa para diferentes componentes das plantas pelas duas espécies, sendo que P. juliflora aloca uma biomassa mais alta para as hastes e Z. spina-christi aloca uma biomassa mais alta para as raízes.

PALAVRAS-CHAVE: Arábia Saudita. Mudas. Recursos. Raiz. Caule.

\section{REFERENCES}

AKASAKA, M.; TSUYUZAKI, S. Tree seedling performance in microhabitats along an elevational gradient on Mount Koma, Japan. Journal of Vegetation Science, v. 16, p. 647-654. 2005. https://doi.org/10.1111/j.1654-1103.2005.tb02407.x

ALSHAHRANI, T. Interactions of allelopathy and competition affecting Ziziphus spina-christi and Prosopis juliflora seedlings. Ph.D. West Virginia University. 2004. 176 p.

BLOSSEY, B.; NOTZOLD, R. Evolution of increased competitive ability in invasive nonindigenous plants: A hypothesis. Journal of Ecology, v. 83, p. 887-889. 1995. https://doi.org/10.2307/2261425

BURNS, J. H.; STACEY, L.; ALICE, H.; WINN, A. A test for a cost of opportunism in invasive species in the Commelinaceae. Biological Invasions, v. 9, p. 213-225. 2007. https://doi.org/10.1007/s10530-006-9027-3

CALDWELL, M.; RICHARDS, J. H.; JOHNSON, D. H.; NOWAK.; R. S.; DZUREC, R. S. Coping with herbivory: photosynthetic capacity and resource allocation in two semiarid Agropyron bunchgrasses.

Oecologia, v. 50, p. 14-24. 1981. https://doi.org/10.1007/BF00378790

CHAPIN, F S III. The mineral nutrition of wild plants. Annual Review of Ecology and Systematics, v. 11, p. 233-260. 1980. https://doi.org/10.1146/annurev.es.11.110180.001313

CLARIDGE, K.; FRANKLIN, S. B. Compensation and plasticity in an invasive plant species. Biological Invasions, v. 4, p. 339-347. 2002. https://doi.org/10.1023/A:1023671006342

CRISÓSTOMO, J A; FREITAS, H.; RODRÍGUEZ-ECHEVERRÍA, S. Relative growth rates of three woody legumes: implications in the process of ecological invasion. Web Ecology, v. 7, p. 22-26. 2007. https://doi.org/10.5194/we-7-22-2007

CRONK, Q. B.; FULLER, J. L. Plant invaders. New York: Chapman and Hall, 1995. 255 p. 
D'ANTONIO, C. M.; HUGHES, R. F.; VITOUSEK, P. M. Factors influencing dynamics of invasive C4 grasses in Hawaiian woodland, role of resource competition and priority effects. Ecology, v. 82, p. 89-104. 2001. https://doi.org/10.1890/0012-9658(2001)082[0089:FIDOTI]2.0.CO;2 https://doi.org/10.2307/2680088

DAEHLER, C. C. Performance comparisons of co-occurring native and alien invasive plants: implications for conservation and restoration. Annual Review of Ecology, Evolution, and Systematics, v. 34, p. 183-211. 2003. https://doi.org/10.1146/annurev.ecolsys.34.011802.132403

DASH, S.; MOHAPATRA, A. K.; GUPTA, N. Growth response of Dalbergia sissoo Roxb. to mineral solubilizing bacteria and fungi in nursery conditions. Tropical Ecology, v. 54, n. 1, p. 109-115. 2013.

DIAS-FILHO, M. B.; DE CARVALHO, C. J. R. Physiological and morphological responses of Brachiaria spp. to flooding. Pesquisa Agropecuária Brasileira, v. 35, p. 1959-1966. 2000. https://doi.org/10.1590/S0100204X2000001000006

DIAZ, S; HODGSON, J. G.; THOMPSON, K.; CABIDO, M.; CORNELISSEN, J. H. C.; JALILI, A.; MONTSERRAT-MARTÍ, G.; GRIME, J. P.; ZARRINKAMAR, F.; ASRI, Y.; BAND, S. R.; BASCONCELO, S.; CASTRO-DÍEZ, P.; FUNES, G.; HAMZEHEE, B.; KHOSHNEVI, M.; PÉREZHARGUINDEGUY, N.; PÉREZ-RONTOMÉ, M.C; SHIRVANY, F. A.; VENDRAMINI. F.; YAZDANI, S.; ABBAS-AZIMI, R.; BOGAARD, A.; BOUSTANI, S.; CHARLES, M.; DEHGHAN, M.; DE TORRESESPUNY, L.; FALCZUK, V.; GUERRERO-CAMPO, J.; HYND, A.; JONES, G.; KOWSARY, E.; KAZEMISAEED, F.; MAESTRO-MARTÍNEZ, M.; ROMO-DÍEZ, A.; SHAW, S.; SIAVASH, B.; VILLARSALVADOR, P.; ZAK, M. R. The plant traits that drive ecosystems: evidence from three continents. Journal of Vegetation Science, v. 15, n. 3, p. 295-304. 2004. https://doi.org/10.1111/j.1654-1103.2004.tb02266.x

DURAND, L. Z.; GOLDSTEIN, G. Growth, leaf characteristics, and spore production in native and invasive tree ferns in Hawaii. American Fern Journal, v. 91, n. 1, p. 25-35. 2001. https://doi.org/10.1640/00028444(2001)091[0025:GLCASP]2.0.CO;2

EHRENFELD, J. G. Effects of exotic plant invasions on soil nutrient cycling processes. Ecosystems, v. 6, p. 503-523. 2003. https://doi.org/10.1007/s10021-002-0151-3

FENG, Y. L.; FU, G. L.; ZHENG, Y. L. Specific leaf area relates to the differences in leaf construction cost, photosynthesis, nitrogen allocation, and use efficiencies between invasive and noninvasive alien congeners. Planta, v. 228, p. 383-390. 2008. https://doi.org/10.1007/s00425-008-0732-2

GARCIA-SERRANO, H.; ESCARRE, J.; GARNIER, E.; SANS, X. F. A comparative growth analysis between alien invader and native Senecio species with distinct distribution ranges. Ecoscience, v. 12, p. 35-43. 2005. https://doi.org/10.2980/i1195-6860-12-1-35.1

GLEASON, S. M.; ARES, A. Photosynthesis, carbohydrate storage and survival of a native and an introduced tree species in relation to light and defoliation. Tree Physiology, v. 24, p. 1087-1097. 2004.

https://doi.org/10.1093/treephys/24.10.1087

GOEL, U.; SAXENA, D. B.; KUMAR, B. Comparative study of allelopathy as exhibited by Prosopis juliflora Swartz and Prosopis cineraria (L) Druce. Journal of Chemical Ecology, v. 15, p. 591-600. 1989. https://doi.org/10.1007/BF01014703

GROTKOPP, E.; REJMÁNEK, M. High seedling relative growth rate and specific leaf area are traits of invasive species: phylogenetically independent contrasts of woody angiosperms. American Journal of Botany, v. 94 n. 4, p. 526-532. 2007. https://doi.org/10.3732/ajb.94.4.526 
GROTKOPP, E.; REJMÁNEK, M.; ROST, T. L. Toward a causal explanation of plant invasiveness: seedling growth and life-history strategies of 29 pine (Pinus) species. The American Naturalist, v. 159, n 4, p. 396419. 2002. https://doi.org/10.2307/3079249 https://doi.org/10.1086/338995

GUPTA, S.; NARAYAN, R. Phenotypic plasticity of Chenopodium murale across contrasting habitat conditions in peri-urban areas in Indian dry tropics: Is it indicative of its invasiveness? Plant Ecology, v. 213, n. 3, p. 493-503. 2012. https://doi.org/10.1007/s11258-011-9997-9

JAMES, J. J.; DRENOVSKY, R. E. A basis for relative growth rate differences between native and invasive forb seedlings. Rangeland Ecology and Management, v. 60, n. 4, p. 395-400. 2007. https://doi.org/10.2111/1551-5028(2007)60[395:ABFRGR]2.0.CO;2

JOHNSON, C.; STOUT, P.; BROYER, T.; CARLTON, A. Comparative chlorine requirements of different plant species. Plant and Soil, v. 8, p. 337-353. 1957. https://doi.org/10.1007/BF01666323

KEANE, R. M.; CRAWLEY, M. J. Exotic plant invasions and the enemy release hypothesis. Trends in Ecology and Evolution, v. 17, p. 164-170. 2002. https://doi.org/10.1016/S0169-5347(02)02499-0

KNAPP, A. K.; BRIGGS, J. M.; BLAIR, J. M.; TURNER, C. L. Patterns and controls of aboveground net primary production in tallgrass prairie. In: KNAPP, A. K.; BRIGGS, J. M.; HARTNETT, D. C.; COLLINS, S. L. (Ed.). Grassland dynamics: long-term ecological research in tallgrass prairie. New York: Oxford University Press, 1998. p. 193-221.

LAMBERS, H.; DIJKSTRA, P. A physiological analysis of genotypic variation in relative growth rate: Can growth rate confer ecological advantage? In: VAN ANDEL, J.; BAKKER, J. P.; SNAYDON, R. W. (Ed.). Disturbance in Grasslands. Dordrecht: Junk, 1987. p. 237-252. https://doi.org/10.1007/978-94-009-4055-0_16

LYNCH, J. Root architecture and plant productivity. Plant Physiology, v. 109, p. 7-13. 1995. https://doi.org/10.1104/pp.109.1.7

PATTISON, R. R.; GOLDSTEIN, G.; ARES, A. Growth, biomass allocation and photosynthesis of invasive and native Hawaiian rainforest species. Oecologia, v. 117, p. 449-459. 1998.

https://doi.org/10.1007/s004420050680

POORTER, H. Interspecific variation in relative growth rate: on ecological causes and physiological consequences. In: LAMBERS, H. (Ed.). Causes and consequences of variation in growth rate and productivity of higher plants. The Hague: SPB Academic Publishing, 1989. p. 45-68.

PORTÉ, A. J.; LAMARQUE, L. J.; LORTIE, C. J.; MICHALET, R.; DELZON, S. Invasive Acer negundo outperforms native species in non-limiting resource environments due to its higher phenotypic plasticity. BMC Ecology, v. 11, n. 28, p. 1-12. 2011. https://doi.org/10.1186/1472-6785-11-28

QIN, Z.; MAO, D. J.; QUAN, G. M.; ZHANG, J.; XIE, J. F.; DITOMMASO, A. Physiological and morphological responses of invasive Ambrosia artemisiifolia (common ragweed) to different irradiances. Botany, v. 90, p. 1284-1294. 2012. https://doi.org/10.1139/b2012-096

RADOSEVICH, S. R.; HOLT, J. S.; GHERSA, C. M. Ecology of weeds and invasive plants. Relationship to Agriculture and Natural Resource Management. 3. ed. New York: John Wiley and Sons Inc., 2007. 454 p. https://doi.org/10.1002/9780470168943

TORCHIN, M. E.; LAFFERTY, K. D.; DOBSON, A. P.; MCKENZIE, V. J.; KURIS, A. M. Introduced species and their missing parasites. Nature, v. 421, p. 628-630. 2003. https://doi.org/10.1038/nature01346 
VILÀ, M.; WEINER, J. Are invasive plant species better competitors than native plant species?—evidence from pair-wise experiments. Oikos, v. 105, p. 229-239. 2004. https://doi.org/10.1111/j.00301299.2004.12682.x

VITOUSEK, P. Biological invasions and ecosystem properties: can species make a difference? In: MOONEY, H. A.; DRAKE, J. A. (Ed.). Ecology of biological invasions of North America and Hawaii. New York: Springer-Verlag, 1996. p. 163-176.

WILLIAMS, D.; BLACK, R. Drought response of a native and introduced Hawaiian grass. Oecologia, v. 97, n. 4, p 512-519. 1994. https://doi.org/10.1007/BF00325890

WILSEY, B. J.; POLLEY, H. W. Aboveground productivity and root-shoot allocation differ between native and introduced grass species. Oecologia, v 150, n. 2, p. 300-309. 2006. https://doi.org/10.1007/s00442-0060515-z

ZHENG, Y. L.; FENG, Y. L.; LIU, W. X.; LIAO, Z. Y. Growth, biomass allocation, morphology, and photosynthesis of invasive Eupatorium adenophorum and its native congeners grown at four irradiances. Plant Ecology, v. 203, n. 2, p. 263-271. 2009. https://doi.org/10.1007/s11258-008-9544-5 